\title{
Strategi Pengembangan Usaha Budidaya Ikan Konsumsi Air Tawar dan Ikan Hias Air Tawar pada Kelompok Mitra Posikandu Kabupaten Bogor
}

\author{
Business Expansion Strategies on Consumable Freshwater Fish and Decorative Fish Breeding in \\ Kelompok Mitra Posikandu Bogor District
}

Bagus Dwi Nugroho*1, Hartrisari Hardjomidjojo², dan Ma'mun Sarma ${ }^{3}$

${ }^{1}$ Dinas Perikanan dan Peternakan

Jl. Bersih Kelurahan Tengah Kecamatan Cibinong 16911

${ }^{2}$ Departemen Teknologi Industri Pertanian, Fakultas Teknologi Pertanian Institut Pertanian Bogor

Jl. Lingkar Akademik, Kampus IPB Darmaga, Bogor 16680

${ }^{3}$ Departemen Manajemen, Fakultas Ekonomi dan Manajemen Institut Pertanian Bogor

Jl. Agatis, Kampus IPB Darmaga, Bogor 16680

\begin{abstract}
ABSTRAK
Perikanan merupakan salah satu sektor unggulan yang dimiliki oleh Kabupaten Bogor. Kabupaten Bogor memiliki visi menjadi kabupaten termaju di Indonesia dengan salah satu penciri adalah produksi benih ikan hias dan benih ikan konsumsi air tawar terbanyak di Indonesia. Total produksi ikan konsumsi mencapai 112.781 ton dan ikan hias 242.520.230 ekor benih. Kelompok Mitra Posikandu adalah kelompok budidaya ikan yang terletak pada Kawasan Minapolitan Kabupaten Bogor. Kelompok ini didirikan pada bulan Agustus 2016 dengan jumlah anggota kelompok 23 orang. Tujuan dari penelitian ini adalah (1) mendapatkan informasi tentang kelompok Mitra Posikandu, (2) mengidentifikasi faktor internal dan eksternal pada kelompok Mitra Posikandu, (3) merumuskan strategi pengembangan usaha kelompok Mitra Posikandu. Metode analisis terdiri atas analisis faktor internal dengan Internal Faktor Evaluation (IFE), dan menganalisis faktor eksternal dengan External Factor Evaluation (EFE). Perumusan alternatif strategi pengembangan usaha dengan metode Strengths, Weaknesses, Opportunities and Threats (SWOT). Dilanjutkan strategi alternatif menggunakan Analityc Hierarchy Process (AHP).
\end{abstract}

Kata kunci: budidaya ikan konsumsi air tawar, budidaya ikan hias, kelompok mitra posikandu, strategi pengembangan usaha

\section{ABSTRACT}

Fisheries is a prominent sector in Bogor District, in line with its vision to be the most advanced district in Indonesia by becoming the biggest producer of both decorative and consumable fish. Total production of consumable fish has reached 112.781 tons and production of decorative fish has reached 242.520.230 seeds. Kelompok Mitra Posikandu is a group of fish breeder which is located in Minapolitan Area, Bogor District. The group was established in August 2016 with 23 members. The newly established group has several potencies to grow and expand, hence need a research to be carrried out. Internal Factor Evaluation (IFE) and External Factor Evaluation (EFE) methods were used in this research to analyze both internal and external factors. Alternative strategies for business expansion were explained with Strengths, Weaknesses, Opportunities and Threats (SWOT) method and further analyzed by using Analytical Hierarchy Process (AHP).

Key words: business expansion strategies, freshwater fish farming, ornamental fish farming, posikandu partners group

\footnotetext{
*) Korespondensi:

Jl. Bersih Keluarahan Tengah Kecamatan Cibinong Dinas Perikanan dan Peternakan; email: baguspapua@gmail.com
} 


\section{PENDAHULUAN}

Kontribusi pengembangan sektor perikanan dalam upaya peningkatan perekonomian Indonesia dapat dijadikan isu pokok mengingat potensi sektor perikanan Indonesia yang besar, akan tetapi belum dimanfaatkan secara optimal. Saragih) 2010) mengungkapkan pengembangan sektor perikanan sebagai sumber pertumbuhan perekonomian baru di Indonesia sangat memungkinkan. Hal ini didasarkan pada: (1) Potensi sumberdaya perikanan Indonesia tersedia cukup besar; (2) Sektor perikanan merupakan sumber bahan baku protein hewani dan bahan baku industri-industri domestik; (3) Beberapa komoditas perikanan Indonesia mempunyai daya keunggulan komparatif di pasar internasional; dan (4) Kemampuan sektor perikanan menyerap tenaga kerja, meningkatkan dan meratakan pendapatan masyarakat.

Wilayah di Indonesia yang memiliki potensi perikanan yang dapat dikembangkan, khususnya dibidang budidaya perikanan. Menurut Direktorat Jenderal Perikanan Budidaya (2015), nilai produksi perikanan budidaya pada tahun 2015 mengalami pertumbuhan 46,94\% dibandingkan dengan tahun 2014 yang mencapai 11,5 trilliun Rupiah. Tren positif dari produksi perikanan budidaya mengalami peningkatan sejak tahun 2009. Peningkatan pertumbuhan terlihat dari sektor budidaya kolam dengan pertumbuhan $43,76 \%$.

Kabupaten Bogor merupakan daerah dengan potensi perikanan budidaya air tawar yang cukup besar di Provinsi Jawa Barat, dengan jumlah produksi 112.781 ton. Komoditas unggulan yaitu ikan lele, mas, nila, patin dan gurame. Produksi budidaya ikan air tawar dalam kolam didominasi oleh mas, lele, patin, nila dan gurame (Tabel 1). Lima jenis ikan tersebut menyumbang lebih dari $80 \%$ dari total produksi. Perikanan budidaya mempunyai nilai strategis dalam perekonomian nasional karena di samping kontribusinya dalam mendukung usaha peme- nuhan gizi protein hewani, penyedia lapangan kerja dan meningkatkan sumber pendapatan masyarakat, perikanan budidaya juga sebagai sumber devisa negara (Direktorat Jenderal Perikanan Budidaya, 2015).

Ikan hias di Indonesia mempunyai pasar yang besar, baik ikan hias air tawar maupun ikan hias air laut. Kurang lebih 1.100 spesies ikan hias air tawar yang diperdagangkan secara global dan Indonesia memiliki 400 spesies, namun hanya sekitar 90 spesies yang dibudidayakan masyarakat. Ikan hias air tawar asli Indonesia yang menjadi komoditas unggulan adalah ikan arwana dan cupang. Menurut Direktorat Jenderal Perikanan Budidaya (2015), ikan yang berasal dari negara lain dan bisa didomestikasi serta cukup popular dibudidayakan di Indonesia antara lain koki, koi, discus dan guppy. Dinas Peternakan dan Perikanan (2014) mengungkapkan Produksi ikan hias air tawar pada Kabupaten Bogor tahun 2014 mencapai 235.173.740 dan meningkat pada Tahun 2015 mencapai 242.520.230 ekor. Peningkatan kapasitas produksi ikan hias di Kabupaten Bogor menunjukkan bahwa sektor budidaya ikan hias merupakan sektor yang menjanjikan dengan didukung depo ikan hias yang ada di wilayah Kecamatan Cibinong, Kecamatan Laladon dan Kecamatan Parung sebagai sarana pemasaran dari produk ikan hias.

Komoditas unggulan ikan hias Kabupaten Bogor adalah koki, koi, discus, guppy, cupang, corydoras, plati coral, dan ikan neon tetra. Tumbuhnya kelompok-kelompok pembudidaya ikan, asosiasi ikan hias dan komunitas ikan hias serta banyaknya kontes-kontes ikan hias sangat mendukung terhadap perkembangan budidaya ikan hias di Jawa Barat, termasuk di Kabupaten Bogor. Selain itu Kabupaten Bogor memiliki beberapa fasilitas dalam menunjang pertumbuhan industri ikan hias diantaranya pusat pengembangan dan pemasaran ikan hias di bawah pimpinan Direktorat Jenderal Pengolahan dan Pemasaran Hasil Perikanan Kementerian Kelautan dan Perikanan yaitu RAISER, yang memiliki

Tabel 1. Produksi unggulan ikan konsumsi air tawar Kabupaten Bogor

\begin{tabular}{llccccc}
\hline \multirow{2}{*}{ No } & \multirow{2}{*}{ Komoditas } & \multicolumn{5}{c}{ Produksi Ikan Konsumsi Kabupaten Bogor (Ton) } \\
\cline { 3 - 7 } & & 2011 & 2012 & 2013 & 2014 & 2015 \\
\hline 1 & Lele & 33.922 & 47.733 & 64.047 & 79.640 & 82.030 \\
2 & Mas & 9.042 & 10.557 & 9.241 & 11.179 & 11.213 \\
3 & Nila & 6.133 & 6.585 & 6.832 & 8.095 & 8.338 \\
4 & Gurame & 2.340 & 3.783 & 4.065 & 5.124 & 5.277 \\
5 & Patin & 2.570 & 2.645 & 2.955 & 3.148 & 3.242 \\
\hline
\end{tabular}

Sumber: Dinas Peternakan dan Perikanan, 2015 
peranan menjembatani pelaku pembudidaya ikan hias untuk menjual produk baik domestik maupun internasional. Selain itu Kabupaten Bogor memiliki pasar ikan hias yang tersebar pada kecamatan yang memiliki potensi ikan hias.

Tingkat konsumsi ikan per kapita di Kabupaten Bogor periode 5 tahun terakhir ini telah mengalami peningkatan $(26,41 \mathrm{~kg} / \mathrm{kap} /$ tahun pada tahun 2015), tetapi angkanya masih di bawah Pola Pangan Harapan (PPH) 31,40 kg/kap/ thn. Rendahnya tingkat konsumsi ikan ini disebabkan oleh beberapa faktor seperti kondisi ekonomi masyarakat, kurang optimalnya suplai ikan bermutu dan belum berkembangnya jaringan distribusi yang merata. Konsumsi ikan perkapita masyarakat Kabupaten Bogor terus meningkat dengan rataan kenaikan 5,47\% per tahun (Dinas Peternakan dan Perikanan, 2015).

Menurut Dinas Peternakan dan Perikanan (2015), visi Kabupaten Bogor adalah menjadi kabupaten termaju di Indonesia. Visi ini ditunjang dengan 25 penciri kabupaten termaju salah satunya memiliki produksi ikan hias dan ikan konsumsi air tawar terbanyak di Indonesia. Kelompok Mitra Posikandu merupakan salah satu kelompok budidaya yang terletak di kawasan minapolitan dengan memiliki letak strategis, sarana dan prasarana budidaya, dan mampu menerima inovasi baru membuat kelompok memiliki potensi untuk berkembang. Dengan terus meningkatnya permintaan produk perikanan kelompok harus memiliki strategi untuk bertahan atau berkembang dalam mengantisipasi hal tersebut. Tujuan penelitian ini adalah (1) Menganalisis situasi budidaya ikan konsumsi air tawar dan ikan hias yang ada pada Pokdakan Mitra Posikandu; (2) Mengidentifikasi faktor internal dan eksternal pada Pokdakan Mitra Posikandu; (3) Merumuskan strategi pengem-bangan usaha Pokdakan Mitra Posikandu.

\section{METODE PENELITIAN}

Analisis situasi mengumpulkan informasi jenis dan bentuk kegiatan, pihak atau publik yang terlibat. Faktor Eksternal dan Internal dilakukan untuk mengetahui posisi usaha budidaya perikanan dengan sistem pakar. Data yang telah diperoleh dalam analisis IFE (Internal Factor Evaluation) dan EFE (External Factor Evaluation) diolah secara keseluruhan melalui matriks SWOT, lalu beberapa strategi pengembangan diolah menggunakan Analityc Hierarchy Process (AHP) melalui expert choice 11. Kerangka pemikiran penelitian dapat dilihat pada Gambar 1.

Penelitan ini dilakukan pada kelompok budidaya ikan Mitra Posikandu yang terletak pada Kecamatan Ciseeng, Kecamatan Parung, Kecamatan Gunungsindur dan Kecamatan Kemang yang merupakan Kawasan Minapolitan Kabupaten Bogor. Pengumpulan data dan penelitian dilakukan selama tiga bulan yaitu bulan Februari-April 2017. Jenis pengumpulan data yang dilakukan dalam penelitian ini dikelompokkan menjadi dua, yaitu data primer dan sekunder. Tahapan Penelitian dapat dilihat pada Tabel 2.

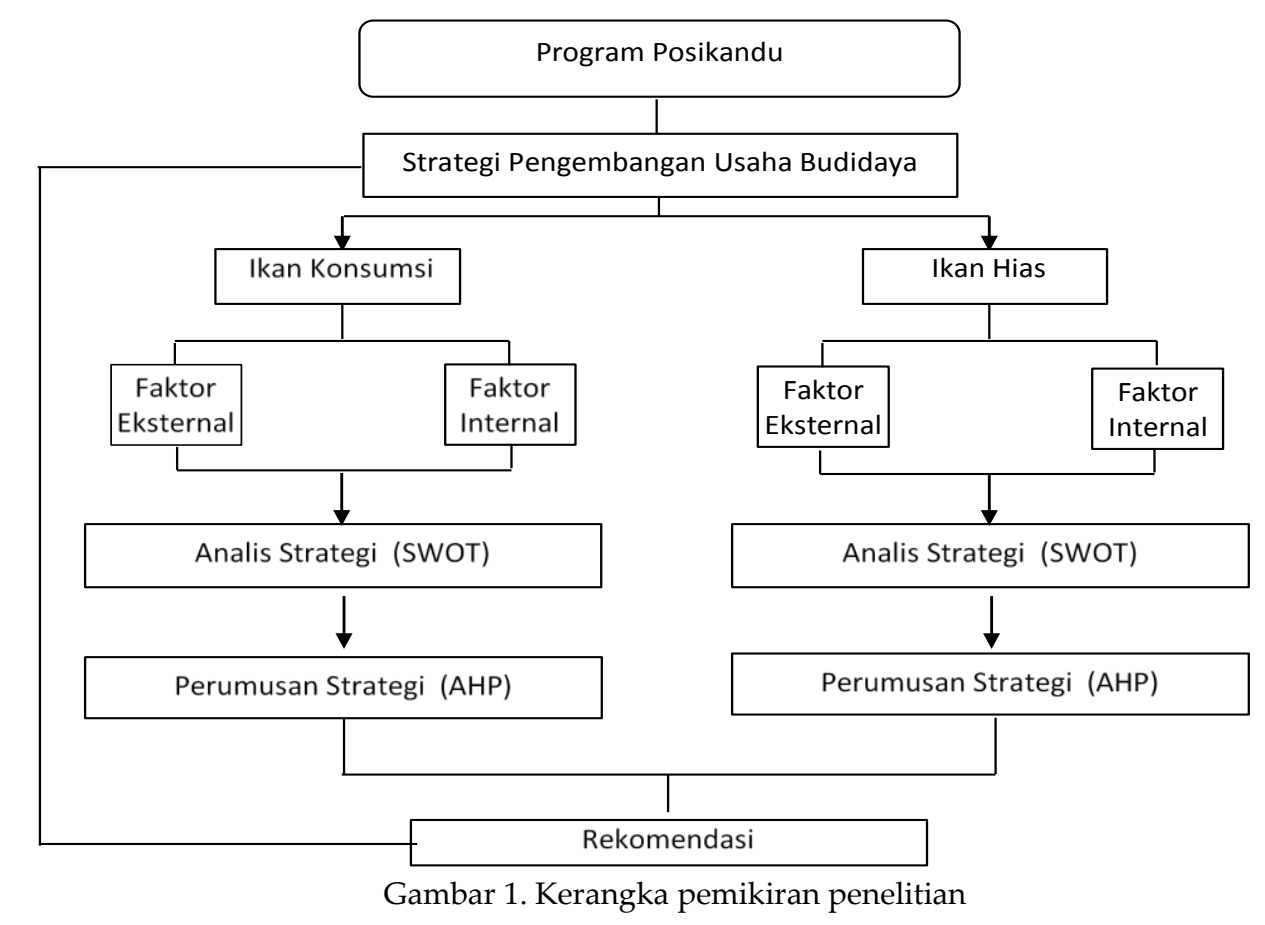


Tabel 2. Tahapan penelitian, metode dan keluaran

\begin{tabular}{lllll}
\hline No & \multicolumn{1}{c}{ Tahapan } & \multicolumn{1}{c}{ Sub tahapan } & Metode / tool & Keluaran \\
\hline 1 & Analisis Situasi & Identifikasi situasi budidaya \\
& Analisis & $\begin{array}{l}\text { Wawancara, pengumpulan } \\
\text { hias. }\end{array}$ & $\begin{array}{l}\text { Mengetahui kondisi terkini } \\
\text { data sekunder dan primer }\end{array}$ & $\begin{array}{l}\text { Usaha Budidaya Ikan } \\
\text { Konsumsi dan Ikan Hias }\end{array}$ \\
\hline 2 & Analisis SWOT & $\begin{array}{l}\text { Identifikasi faktor internal } \\
\text { dan eksternal }\end{array}$ & $\begin{array}{l}\text { Perbandingan Berpasangan } \\
\text { sistem pakar }\end{array}$ & $\begin{array}{l}\text { Mengetahui posisi kekuatan, } \\
\text { kelemahan, peluang, ancaman } \\
\text { usaha budidaya dan alternatif }\end{array}$ \\
& & & strategi peningkatan usaha \\
\hline 3 & $\begin{array}{l}\text { Penentuan } \\
\text { Strategi }\end{array}$ & $\begin{array}{l}\text { Mengolah alternatif strategi } \\
\text { peningkatan usaha budidaya }\end{array}$ & AHP / Expert Choice 11 & $\begin{array}{l}\text { Penentuan strategi } \\
\text { peningkatan usaha }\end{array}$ \\
\hline
\end{tabular}

\section{HASIL DAN PEMBAHASAN}

\section{Identifikasi Faktor-Faktor Penentu Strategi}

Proses perumusan strategi pengembangan budidaya ikan konsumsi air tawar dan ikan hias air tawar dilakukan dengan melihat dan menganalisis lingkungan budidaya ikan. Analisis dilakukan dengan melihat lingkungan internal dan eksternal yang memengaruhi pengembangan industri budidaya. Identifikasi faktor-faktor penentu strategi berdasarkan analisis SWOT.

Penilaian dalam analisis SWOT dibagi kedalam dua kelompok, yakni faktor internal (IFAS) yang terdiri dari kekuatan (strength) dan kelemahan (weakness) dan faktor ekternal (EFAS) terdiri dari peluang (opportunity) dan ancaman (threat). Faktor-faktor tersebut diidentifikasi dalam strategi perencanaan yang dipakai sebagai dasar menentukan perbaikan yang diperlukan dalam pengembangan selanjutnya. Analisis strategi dilakukan dengan analisa SWOT dengan perangkat IFAS dan EFAS. Dalam mengevaluasi faktor internal yang akan memengaruhi pengembangan usaha budidaya ikan konsumsi, dilakukan identifikasi terhadap faktor-faktor strategik internal dan eksternal. Hasil wawancara dan kuesioner yang diberikan kepada responden didapatkan beberapa faktor secara internal dan eksternal seperti dimuat pada pada Tabel 3 dan 4 .

Data pada Tabel 3 menunjukkan faktorfaktor yang memengaruhi usaha budidaya ikan konsumsi berikut sumber resikonya berdasarkan hasil observasi dan wawancara dengan alat bantu kuesioner. Resiko internal adalah resiko yang terkait dengan kegagalan proses atau prosedur yang terdapat pada usaha budidaya ikan konsumsi, adapun resiko eksternal adalah resiko yang timbul dari kegiatan diluar usaha budidaya ikan konsumsi namun keberhasilan atau kegagalan pengelolaannya sangat mempengaruhi keberhasilan dari kelompok Mitra Posikandu. Faktor yang memengaruhi pengembangan usaha Kelompok Mitra Posikandu selanjutnya dihitung untuk mengetahui faktor dominan yang paling berpengaruh terhadap kinerja. Analisis untuk mengetahui faktor yang paling berpengaruh diolah dengan expert choice 11.

Tabel 3. Faktor internal dan eksternal ikan konsumsi air tawar kelompok Mitra Posikandu

\begin{tabular}{|c|c|c|}
\hline Aspek & Faktor-faktor yang memengaruhi kinerja kelompok & Sumber resiko \\
\hline \multirow[t]{5}{*}{ 1. Produksi } & Letak kelompok strategis (minapolitan) & Internal \\
\hline & Mutu produk mutu(CBIB) & Internal \\
\hline & Sarana dan prasarana budidaya & Internal \\
\hline & Harga pakan tinggi & Internal \\
\hline & Alih fungsi lahan budidaya & Eksternal \\
\hline \multirow[t]{8}{*}{ 2. SDM } & Tidak tercatatnya administrasi kelompok & Internal \\
\hline & Pendidikan rendah & Internal \\
\hline & Usia anggota kelompok & Internal \\
\hline & Kreatifitas & Internal \\
\hline & Pengalaman budidaya & Internal \\
\hline & Adopsi inovasi baru & Internal \\
\hline & Komunikasi antar anggota kelompok & Internal \\
\hline & Bantuan Pemda & Eksternal \\
\hline \multirow[t]{6}{*}{ 3. Keuangan } & Harga jual produk oleh pengumpul & Eksternal \\
\hline & Persaingan produk dari luar Jawa Barat & Eksternal \\
\hline & Modal produksi terbatas & Internal \\
\hline & Permintaan produk terus meningkat & Eksternal \\
\hline & Kepuasan pelanggan & Eksternal \\
\hline & Reputasi & Eksternal \\
\hline
\end{tabular}


Tabel 4. Faktor internal dan eksternal ikan hias air tawar kelompok Mitra Posikandu

\begin{tabular}{crlr}
\hline No. & Aspek & Faktor-faktor yang Mempengaruhi Kinerja Kelompok & Sumber Resiko \\
\hline 1. & Produksi & Letak kelompok strategis (minapolitan) & Internal \\
& & Mutu produk berkualitas (CBIB) & Internal \\
& Sarana dan prasarana budidaya & Internal \\
& Harga benih/induk tinggi & Internal \\
& Fluktuasi suhu & Eksternal \\
& Tidak membutuhkan lahan luas & Internal \\
\hline 2. SDM & Tidak tercatatnya administrasi kelompok & Iinternal \\
& Pendidikan rendah & Internal \\
& Usia anggota kelompok & Internal \\
& Menerima inovasi baru & Internal \\
& Komunikasi antar anggota kelompok & Internal \\
& Bantuan Pemda & Eksternal \\
\hline 3. Keuangan & Harga jual produk oleh pengumpul & Eksternal \\
& Persaingan produk dari luar Jawa Barat & Eksternal \\
& Modal produksi terbatas & Internal \\
& Permintaan produk terus meningkat & Eksternal \\
& Kepuasan pelanggan & Eksternal \\
& Ketersediaan pasar ikan hias & Eksternal \\
& Reputasi & Eksternal \\
\hline
\end{tabular}

Data pada Tabel 4, menunjukkan faktorfaktor yang memengaruhi usaha budidaya ikan hias berikut sumber resikonya berdasarkan hasil observasi dan wawancara dengan alat bantu kuesioner. Resiko internal adalah resiko yang terkait dengan kegagalan proses atau prosedur yang terdapat pada usaha budidaya ikan hias, adapun resiko eksternal adalah resiko yang timbul dari kegiatan diluar usaha budidaya ikan konsumsi namun keberhasilan atau kegagalan pengelolaannya sangat memengaruhi keberhasilan dari kelompok Mitra Posikandu. Faktor yang memengaruhi pengembangan usaha Kelompok Mitra Posikandu dipertimbangkan sebagai bahan acuan mengetahui faktor dominan yang paling berpengaruh terhadap kinerja. Analisis untuk mengetahui faktor yang paling berpengaruh diolah dengan expert choice 11.

\section{Analisis SWOT}

Faktor internal dan eksternal dari segmen usaha ikan konsumsi yang telah diolah untuk mengetahui posisi strategik pada usaha budidaya kelompok Mitra Posikandu. Pembobotan dilakukan dengan responden pakar yang diolah dengan expert choice 11 dan rating. Hasil perhitungan untuk ikan konsumsi dimuat pada Tabel 5 dan 6 .

Total nilai yang diperoleh dari matriks IFE Ikan Konsumsi 3,06. Menurut David (2006), posisi nilai tersebut berada di nilai rata-rata tertimbang $(2,5)$. Kondisi tersebut menunjukkan secara internal posisi usaha budidaya saat ini cukup baik dalam memanfaatkan kekuatan-kekuatan dan berupaya untuk mengatasi kelemahan-kelemahan yang ada. Kekuatan utama adalah letak kelompok strategik $(0,808)$ dikarenakan terletak pada kawasan minapolitan yang merupakan konsep pembangunan industri perikanan terintegrasi. Kekuatan selanjutnya komunikasi antar anggota kelompok $(0,568)$, adopsi inovasi baru $(0,447)$, pengalaman dalam budidaya $(0,345)$, Produk bermutu $(0,231)$ dan sarana prasarana budidaya $(0,246)$.

Tabel 5. Evaluasi Faktor Internal Ikan Konsumsi

\begin{tabular}{|c|c|c|c|c|}
\hline \multirow{2}{*}{ No. } & \multirow{2}{*}{ Faktor Internal } & Bobot & Rating & Skor \\
\hline & & (a) & (b) & (a) $x(b)$ \\
\hline \multicolumn{5}{|c|}{ Kekuatan } \\
\hline 1 & $\begin{array}{l}\text { Letak kelompok } \\
\text { strategik }\end{array}$ & 0,202 & 4 & 0,808 \\
\hline 2 & Komunikasi kelompok & 0,142 & 4 & 0,568 \\
\hline 3 & Adopsi inovasi baru & 0,149 & 3 & 0,447 \\
\hline 4 & $\begin{array}{l}\text { Pengalaman } \\
\text { budidaya }\end{array}$ & 0,115 & 3 & 0,345 \\
\hline 5 & Produk bermutu & 0,077 & 3 & 0,231 \\
\hline 6 & Sapras budidaya & 0,082 & 3 & 0,246 \\
\hline \multicolumn{5}{|c|}{ Kelemahan } \\
\hline 7 & Harga pakan tinggi & 0,064 & 2 & 0,128 \\
\hline 8 & Modal & 0,052 & 2 & 0,104 \\
\hline 9 & Tercatat & 0,042 & 2 & 0,084 \\
\hline 10 & Pendidikan & 0,033 & 1 & 0,033 \\
\hline 11 & Usia & 0,024 & 2 & 0,048 \\
\hline 12 & Kreatifitas & 0,018 & 1 & 0,018 \\
\hline \multicolumn{4}{|c|}{ Total IFE Ikan Konsumsi } & 2,23 \\
\hline
\end{tabular}


Faktor kelemahan yang dianggap memberikan pengaruh kepada pengembangan usaha budidaya ikan konsumsi adalah harga pakan yang tinggi dengan skor $(0,128)$, modal terbatas dengan skor $(0,104)$, tidak tercatatnya administrasi kelompok baik catatan produksi maupun keuangan dengan skor $(0,084)$, pendidikan anggota kelompok yang rendah dengan skor $(0,033)$, usia produktif anggota kelompok dengan skor $(0,048)$ dan kreatifitas dengan skor $(0,018)$.

Tabel 6. Evaluasi faktor eksternal ikan konsumsi

\begin{tabular}{|c|c|c|c|c|}
\hline \multirow{2}{*}{ No. } & \multirow{2}{*}{ Faktor Eksternal } & Bobot & Rating & Skor \\
\hline & & (a) & (b) & (a) $x(b)$ \\
\hline \multicolumn{5}{|c|}{ Peluang } \\
\hline 1 & Reputasi & 0,285 & 3 & 0,855 \\
\hline 2 & Kepuasan pelanggan & 0,220 & 4 & 0,880 \\
\hline 3 & Permintaan & 0,196 & 3 & 0,588 \\
\hline 4 & Bantuan Pemda & 0,127 & 3 & 0,381 \\
\hline \multicolumn{5}{|c|}{ Ancaman } \\
\hline 5 & $\begin{array}{l}\text { Pesaing dari luar } \\
\text { Jawa Barat }\end{array}$ & 0,087 & 2 & 0,174 \\
\hline 6 & $\begin{array}{l}\text { Harga jual oleh } \\
\text { pengumpul }\end{array}$ & 0,053 & 2 & 0,106 \\
\hline 7 & $\begin{array}{l}\text { Alih fungsi lahan } \\
\text { budidaya }\end{array}$ & 0,033 & 1 & 0,033 \\
\hline \multicolumn{4}{|c|}{ Total EFE Ikan Konsumsi } & 2,391 \\
\hline
\end{tabular}

Faktor lingkungan ekternal yang memengaruhi pengembangan usaha budidaya ikan konsumsi dilihat dari aspek peluang dan ancaman, dimana terdiri atas tujuh faktor yang terdiri dari empat faktor peluang dan tiga faktor ancaman. Faktor peluang paling berpengaruh adalah kepuasan pelanggan dengan skor $(0,880)$, reputasi dengan skor $(0,855)$, permintaan dengan skor $(0,588)$, dan bantuan dari Pemda dengan skor $(0,381)$.

Ancaman utama yang ada dalam usaha budidaya ikan konsumsi yaitu pesaing produk perikanan yang masuk dari luar jawa barat dengan skor $(0,174)$, harga jual yang ditentukan oleh pedagang pengumpul dengan skor $(0,106)$ dan alih fungsi lahan budidaya untuk kepentingan perumahan dan industri lain sebesar 0,033.

Berdasarkan perhitungan pada Tabel 5 dan 6, posisi usaha budidaya ikan konsumsi berada pada kuadran I $(2,23 ; 2,361)$ sehingga strategi yang diterapkan adalah strategi agresif dengan memaksimalkan kekuatan dan peluang dari kelompok budidaya (Marimin, 2010). Posisi usaha budidaya ikan konsumsi dapat ditunjukkan pada Gambar 2.

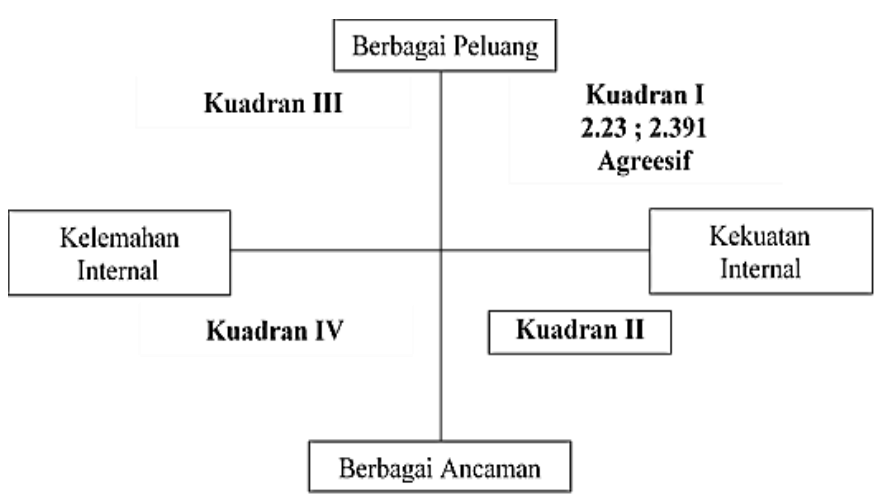

Gambar 2. Posisi usaha ikan konsumsi

\section{Ikan Hias}

Faktor internal dan eksternal dari segmen usaha ikan hias yang telah ditentukan selanjutnya diolah untuk mengetahui posisi strategis pada usaha budidaya kelompok Mitra Posikandu. Pembobotan dilakukan dengan responden pakar diolah dengan expert choice 11 dan rating. Hasil perhitungan untuk ikan konsumsi selengkapnya disajikan pada Tabel 7 dan 8 .

Tabel 7. Evaluasi faktor internal ikan hias

\begin{tabular}{|c|c|c|c|c|}
\hline \multirow{2}{*}{ No } & \multirow{2}{*}{ Faktor Internal } & Bobot & Rating & Skor \\
\hline & & (a) & (b) & (a) $x(b)$ \\
\hline \multicolumn{5}{|c|}{ Kekuatan } \\
\hline 1 & Letak strategis & 0,195 & 4 & 0,780 \\
\hline 2 & $\begin{array}{l}\text { Komunikasi } \\
\text { kelompok }\end{array}$ & 0,163 & 4 & 0,652 \\
\hline 3 & $\begin{array}{l}\text { Menerima inovasi } \\
\text { baru }\end{array}$ & 0,158 & 3 & 0,474 \\
\hline 4 & Efisien lahan & 0,129 & 3 & 0,387 \\
\hline 5 & Mutu produk & 0,088 & 3 & 0,264 \\
\hline 6 & Sapras budidaya & 0,076 & 3 & 0,228 \\
\hline \multicolumn{5}{|c|}{ Kelemahan } \\
\hline 7 & Harga benih/induk & 0,061 & 2 & 0,122 \\
\hline 8 & Kurangnya modal & 0,047 & 2 & 0,094 \\
\hline 9 & Tercatat & 0,036 & 2 & 0,072 \\
\hline 10 & Pendidikan & 0,028 & 1 & 0,028 \\
\hline 11 & Usia & 0,019 & 1 & 0,019 \\
\hline \multicolumn{4}{|c|}{ Total IFE Ikan Hias } & 2,594 \\
\hline
\end{tabular}

Total nilai yang diperoleh dari matriks IFE ikan hias sebesar 3,12. Menurut David (2006), posisi nilai tersebut berada diatas nilai rata-rata tertimbang yaitu $(2,5)$. Kondisi tersebut menunjukkan secara internal posisi usaha budidaya ikan hias saat ini cukup baik dalam memanfaatkan kekuatan-kekutatan dan berupaya mengatasi kelemahan-kelemahan yang ada. Adapun kekuat- 
an yang merupakan kekuatan utama dalam budidaya ikan hias kelompok Mitra Posikandu adalah letak kelompok strategis dimana kelompok berada pada Kawasan Minapolitan (0,78). Kekuatan selanjutnya adalah komunikasi antar anggota kelompok dengan skor $(0,652)$, menerima inovasi baru dengan skor $(0,474)$, tidak membutuhkan lahan yang luas dalam budidaya dengan skor $(0,387)$, mutu produk berkualitas dengan skor $(0,264)$ dan sarana prasarana budidaya dengan skor $(0,228)$.

Faktor kelemahan yang dianggap memberikan pengaruh terhadap pengembangan usaha budidaya ikan hias adalah harga benih atau induk yang tinggi $(0,122)$, kurangnya modal usaha bagi anggota kelompok $(0,094)$, administrasi kelompok yang tidak tercatat $(0,072)$, pendidikan rata-rata anggota kelompok yang rendah $(0,028)$ dan usia anggota kelompok $(0,019)$

Tabel 8. Evaluasi faktor eksternal ikan hias

\begin{tabular}{|c|c|c|c|c|}
\hline \multirow{2}{*}{ No } & \multirow{2}{*}{ Faktor Eksternal } & Bobot & Rating & Skor \\
\hline & & (a) & (b) & (a) $x(b)$ \\
\hline \multicolumn{5}{|c|}{ Peluang } \\
\hline 1 & Bantuan Pemda & 0,264 & 3 & 0,792 \\
\hline 2 & $\begin{array}{l}\text { Ketersediaan pasar } \\
\text { ikan hias }\end{array}$ & 0,2 & 3 & 0,6 \\
\hline 3 & Permintaan & 0,169 & 3 & 0,507 \\
\hline 4 & Reputasi & 0,12 & 3 & 0,36 \\
\hline 5 & Kepuasan pelanggan & 0,095 & 4 & 0,38 \\
\hline \multicolumn{5}{|c|}{ Ancaman } \\
\hline 6 & $\begin{array}{l}\text { Pesaing dari luar jawa } \\
\text { barat }\end{array}$ & 0,07 & 1 & 0,07 \\
\hline 7 & $\begin{array}{l}\text { Harga jual ditentukan } \\
\text { oleh pengumpul }\end{array}$ & 0,05 & 2 & 0,1 \\
\hline 8 & Fluktuasi suhu & 0,032 & 2 & 0,064 \\
\hline
\end{tabular}

Faktor lingkungan ekternal yang memengaruhi pengembangan usaha budidaya ikan hias dilihat dari aspek peluang dan ancaman, dimana terdiri atas delapan faktor yang terdiri dari lima faktor peluang dan tiga faktor ancaman. Faktor peluang paling berpengaruh adalah bantuan dari Pemda dengan skor $(0,792)$, adanya pasar ikan hias sebagai sarana pemasaran $(0,6)$, permintaan dengan skor $(0,507)$, reputasi kelompok dengan skor $(0,36)$, dan kepuasan pelanggan dengan skor $(0,38)$.

Ancaman utama yang ada dalam usaha budidaya ikan hias yaitu harga jual yang ditentukan oleh pedagang pengumpul dengan skor $(0,1)$, pesaing produk perikanan yang masuk dari luar jawa barat dengan skor $(0,07)$, dan fluktuasi suhu yang menyebabkan kematian pada ikan $(0,064)$. Bantuan dari pemerintah daerah merupakan faktor peluang utama dari usaha ikan hias dengan skor 0,792, sedangkan harga jual yang fluktuatif oleh pengumpul merupakan faktor ancaman utama dengan skor 0,1. Berdasarkan perhitungan pada Tabel 7 dan 8, maka didapat posisi usaha budidaya ikan Hias berada pada kuadran I $(2,594 ; 2,405)$, sehingga strategi yang diterapkan adalah strategi agresif dengan memaksimalkan kekuatan dan peluang dari kelompok budidaya (Marimin, 2010). Posisi usaha ikan hias dapat dijelaskan pada Gambar 3.

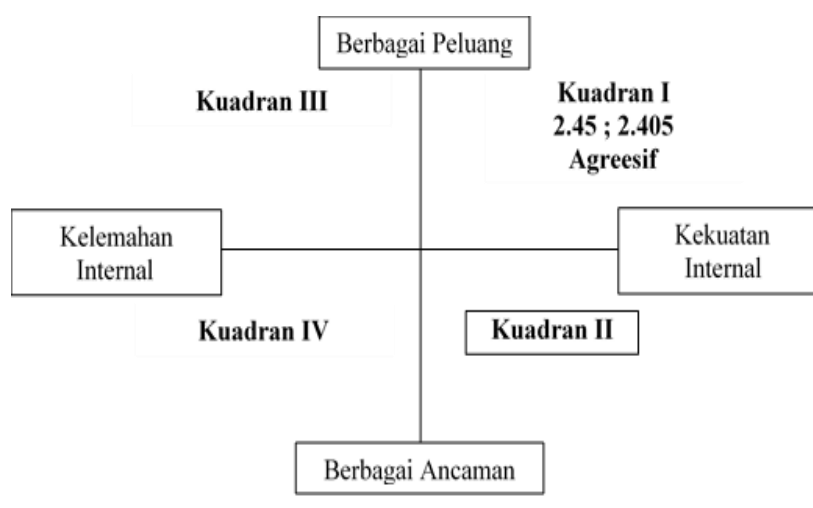

Gambar 3. Posisi usaha ikan hias

\section{Pemilihan Strategi Pengembangan Usaha}

\section{Ikan konsumsi}

Alternatif strategi yang diperoleh dari analisis SWOT adalah: (S1) Peningkatan produksi dan produktivitas anggota kelompok $\left(\mathrm{S}_{4,5,6} \& \mathrm{O}_{2,3}\right)$; (S2) Membentuk Koperasi "Mitra Posikandu" yang difasilitasi oleh Pemda Kabupaten Bogor ( $\mathrm{S}_{1,2}$ \& $\mathrm{O}_{4}$ ); (S3) Pembelajaran anggota kelompok dengan cara pertemuan langsung atau melalui media sosial ( $\left.\mathrm{S}_{2,3,4} \& \mathrm{O}_{1,2,3,4}\right)$; (S4) Memanfaatkan media sosial sebagai sarana promosi produk perikanan ( $\left.S_{1,2,4} \& \mathrm{~T}_{3}\right) ; \quad(\mathrm{S} 5)$ Mengikuti pelatihan yang diselenggarakan oleh pemerintah daerah sebagai upaya peningkatan SDM $\left(\mathrm{W}_{1,2,3} \& \mathrm{O}_{4}\right)$ dan (S6) Menggunakan pakan alami atau pakan tambahan untuk mengurangi biaya produksi ( $\mathrm{W}_{1,2}$ $\left.\& \mathrm{~T}_{1,2}\right)$. Alternatif strategi dapat ditunjukkan pada Gambar 4.

Strategi ST menghasilkan satu strategi, yaitu pemanfaatan media sosial sebagai sarana promosi produk perikanan, permasalahan yang dihadapi para pembudidaya ikan konsumsi adalah harga jual yang dimonopoli oleh pedagang pengumpul. Untuk itu pemanfaatan media sosial sebagai upaya e-commerce untuk memutus tata niaga yang dilakukan pedagang pengumpul, 
sehingga harga jual yang didapat oleh para pembudidaya lebih tinggi.

Strategi WO menghasilkan satu strategi yaitu pembelajaran antar anggota kelompok, yaitu sebagai sarana bertukar pikiran maupun bertukar informasi yang akan membantu dalam proses budidaya maupun proses pemasaran produk perikanan. Kelompok dapat memanfaatkan media sosial sebagai sarana pembelajaran ataupun membuat pertemuan rutin kelompok.

Strategi WT menghasilkan satu strategi, yaitu menggunakan pakan alami atau pakan tambahan untuk mengurangi biaya produksi. Pakan buatan merupakan pakan utama dalam proses budidaya yang harganya mengalami kenaikan dari waktu ke waktu. Penggunaan pakan alami atau pakan tambahan diperlukan untuk mengurangi biaya produksi tinggi akibat pakan buatan.

Rekomendasi strategi dari hasil perhitungan AHP meliputi unsur unsur faktor yang berpengaruh, yaitu faktor SDM dengan skor perhitungan $(0,594)$ dan aktor berpengaruh adalah Pemda $(0,421)$ Alternatif strategi terpilih adalah (S2), yaitu membentuk koperasi "Mitra Posikandu" yang difasilitasi oleh Pemda Kabupaten Bogor $\left(\mathrm{S}_{1,2,6} \& \mathrm{O}_{4}\right)$ seperti yang ditunjukkan Gambar 5.

\begin{tabular}{|c|c|c|}
\hline Eksternal & $\begin{array}{l}\text { Kekuatan (S) } \\
\text { 1. Letak kelompok strategik (minapolitan) } \\
\text { 2. Komunikasi anggota } \\
\text { 3. Adopsi inovasi } \\
\text { 4. Pengalaman budidaya } \\
\text { 5. Produk bermutu } \\
\text { 6. Sarana dan prasarana budidaya }\end{array}$ & $\begin{array}{l}\text { Kelemahan }(\mathrm{W}) \\
\text { 1. Harga pakan tinggi } \\
\text { 2. Modal terbatas } \\
\text { 3. Administrasi tidak tercatat } \\
\text { 4. Pendidikan rendah } \\
\text { 5. Usia } \\
\text { 6. Kreatifitas }\end{array}$ \\
\hline $\begin{array}{l}\text { Peluang }(\mathrm{O}) \\
\text { 1. Reputasi } \\
\text { 2. Kepuasan pelanggan } \\
\text { 3. Permintaan } \\
\text { 4. Bantuan Pemda }\end{array}$ & $\begin{array}{l}\text { Strategi SO } \\
\text { 1. Peningkatan produksi dan produktivitas } \\
\left(\mathrm{S}_{4,5,6} \& \mathrm{O}_{2,3}\right) \\
\text { 2. Membentuk koperasi "Mitra Posikandu“" } \\
\left(\mathrm{S}_{1,2} \& \mathrm{O}_{4}\right) \\
\text { 3. Pembelajaran anggota }\left(\mathrm{S}_{2,3,4} \& \mathrm{O}_{1,2,3}\right)\end{array}$ & $\begin{array}{l}\text { Strategi WO } \\
\text { Mengikuti pelatihan-pelatihan } \\
\left(\mathrm{W}_{\left.1,2,3, \& \mathrm{O}_{4}\right)}\right.\end{array}$ \\
\hline $\begin{array}{l}\text { Ancaman }(\mathrm{T}) \\
\text { 1. Pesaing } \\
\text { 2. Harga jual } \\
\text { 3. Alih fungsi lahan }\end{array}$ & $\begin{array}{l}\text { Strategi ST } \\
\text { Memanfaatkan media sosial sebagai sarana } \\
\text { promosi produk perikanan }\left(\mathrm{S}_{1,2,4} \& \mathrm{~T}_{3}\right)\end{array}$ & $\begin{array}{l}\text { Strategi WT } \\
\text { Menggunakan pakan alami } \\
\text { atau pakan tambahan } \\
\left(\mathrm{W}_{1,2} \& \mathrm{~T}_{1,2}\right)\end{array}$ \\
\hline
\end{tabular}

Gambar 4. Alternatif strategi ikan konsumsi

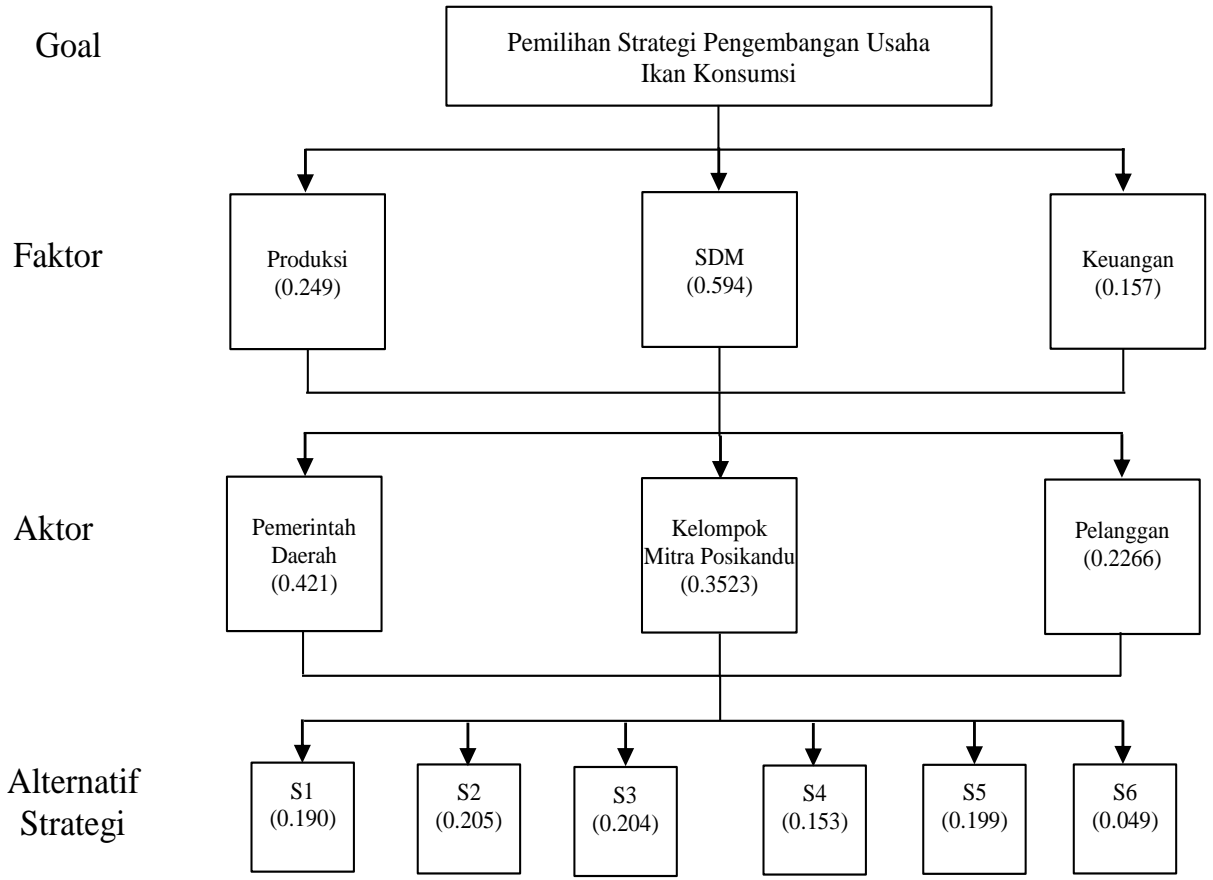

Gambar 5. Diagram alir pemilihan strategi pengembangan usaha budidaya ikan konsumsi 


\section{Ikan Hias}

Alternatif strategi yang diperoleh dari analisis SWOT adalah: (S1) Memanfaatkan fasilitas Pemda berupa depo ikan hias di wilayah minapolitan dengan maksimal ( $\left.\mathrm{S}_{1,6} \& \mathrm{O}_{4}\right)$; (S2) Mengadopsi teknik budidaya ikan hias terbaru untuk meningkatkan mutu produk ( $\left.\mathrm{S}_{3,4,5} \& \mathrm{O}_{1,2}\right)$; (S3) Pertemuan rutin anggota sebagai wadah pertukaran informasi dan pembelajaran (S 2,3\& $\mathrm{O}_{1,2,3)}$; (S4) Membentuk Koperasi Mitra Posikandu yang difasilitasi oleh Pemda ( $2,3,6$ \& $\left.\mathrm{T}_{1,2,3,}\right)$; (S5) mengikuti bimbingan teknis budidaya ataupun bimbingan usaha perikan oleh pemerintah daerah $\left(\mathrm{W}_{2,4} \& \mathrm{O}_{4}\right)$ dan (S6) Studi banding kepada kelompok sejenis yang dinilai lebih maju dan berkembang ( $\left.\mathrm{W}_{1,2,3,4} \& \mathrm{~T}_{1,2,3,}\right)$. Untuk lebih jelasnya alternatif strategi ditujunkan pada Gambar 6.

Strategi ST menghasilkan satu strategi yaitu membentuk koperasi Mitra Posikandu sebagai upaya mengatasi permasalahan pemasaran, biaya produksi dan harga jual yang fluktuatif. Dengan adanya koperasi diharapkan dapat memenuhi kebutuhan dari segi sarana proses produksi budidaya ikan hias.

Strategi WO menghasilkan satu strategi yaitu aktif dalam segala bimbingan teknis maupun bimbingan usaha oleh Pemda. Dengan adanya program pendampingan dan pembinaan kelompok yang dilakukan oleh Pemda, kelompok Mitra Posikandu diharapkan aktif dalam program program yang telah dirancang oleh Pemda.

Strategi WT menghasilkan satu strategi, yaitu melakukan kemitraan pada perusahaan ekportir ikan hias air tawar, Kabupaten Bogor sendiri memiliki perusahaan-perusahaan yang melakukan ekspor ikan hias air tawar ke negara Singapura. Dengan adanya kemitraan, kelompok dapat menjadi salah satu pemasok komoditas ikan hias bagi perusahaan eksportir.

Rekomendasi strategi dari hasil perhitungan AHP meliputi unsur faktor berpengaruh yaitu SDM $(0,570)$ dan aktor berpengaruh yaitu kelompok mitra posikandu (0,521). Alternatif strategi terpilih adalah (S5) yaitu aktif dalam bimbingan teknis budidaya ataupun bimbingan usaha perikanan oleh Pemda $\left(\mathrm{W}_{2,4}\right.$ \& $\left.\mathrm{O}_{4}\right)(0,214)$ seperti yang dimuat dalam Gambar 7 .

\section{KESIMPULAN}

1. Situasi budidaya ikan konsumsi dan ikan hias yang ada pada kelompok Mitra Posikandu memiliki potensi untuk berkembang dengan didukung sarana dan prasarana yang baik, dukungan Pemda, komunikasi yang baik antar anggota, serta memiliki lokasi yang strategis yaitu berada pada kawasan minapolitan. Kendala yang dihadapi kelompok yaitu tingkat SDM yang rendah, harga jual produk yang tidak stabil, modal yang terbatas, serta alih fungsi lahan budidaya sebagai perumahan umum.

2. Simpulan yang dapat ditarik dalam penelitian ini adalah bahwa pengembangan usaha budidaya ikan konsumsi dan ikan hias pada kelompok Mitra Posikandu Kabupaten Bogor merupakan hal yang sangat penting untuk di-

\begin{tabular}{|c|c|c|}
\hline Eksternal & $\begin{array}{l}\text { Kekuatan (S) } \\
\text { 1. Letak kelompok strategik (minapolitan) } \\
\text { 2. Komunikasi antar anggota kelompok } \\
\text { 3. Menerima inovasi } \\
\text { 4. Efisiensi lahan budidaya } \\
\text { 5. Mutu produk } \\
\text { 6. Sarana dan prasarana budidaya }\end{array}$ & \begin{tabular}{ll} 
& \multicolumn{1}{c}{ Kelemahan $(\mathbf{W})$} \\
1. & Harga induk/benih \\
2. & Modal terbatas \\
3. & Administrasi tidak tercatat \\
4. & Pendidikan rendah \\
5. & Usia
\end{tabular} \\
\hline $\begin{array}{l}\quad \text { Peluang (O) } \\
\text { 1. Reputasi } \\
\text { 2. Kepuasan pelanggan } \\
\text { 3. Permintaan } \\
\text { 4. Bantuan Pemda }\end{array}$ & $\begin{array}{l}\text { Strategi } S O \\
\text { 1. Memanfaatkan fasilitas Pemda berupa depo } \\
\text { ikan hias di wilayah minapolitan dengan } \\
\text { maksimal }\left(\mathrm{S}_{1,6} \& \mathrm{O}_{4}\right) \\
\text { 2. Mengadopsi teknik budidaya ikan hias } \\
\text { terbaru }\left(\mathrm{S}_{3,4,5} \& \mathrm{O}_{1,2}\right) \\
\text { 3. Pertemuan rutin anggota }\left(\mathrm{S}_{2,3} \& \mathrm{O}_{1,2,3}\right)\end{array}$ & $\begin{array}{l}\text { Strategi } W O \\
\text { Aktif dalam bimbingan teknis } \\
\left(\mathrm{W}_{2,4} \& \mathrm{O}, 4\right)\end{array}$ \\
\hline $\begin{array}{l}\text { Ancaman (T) } \\
\text { 1. Pesaing dari luar Jawa Barat } \\
\text { 2. Harga oleh pengumpul } \\
\text { 3. Kematian oleh fluktuasi suhu }\end{array}$ & $\begin{array}{l}\text { Strategi ST } \\
\text { Membentuk Koperasi Mitra Posikandu yang } \\
\text { difasilitasi oleh Pemda }\left(S_{2,3,6} \& T_{1,2,3}\right)\end{array}$ & $\begin{array}{l}\text { Strategi WT } \\
\text { Studi banding kepada kelompok } \\
\text { sejenis }\left(\mathrm{W}_{1,2,3,4} \& \mathrm{~T}_{1,2,3,}\right)\end{array}$ \\
\hline
\end{tabular}

Gambar 6. Alternatif strategi ikan hias 


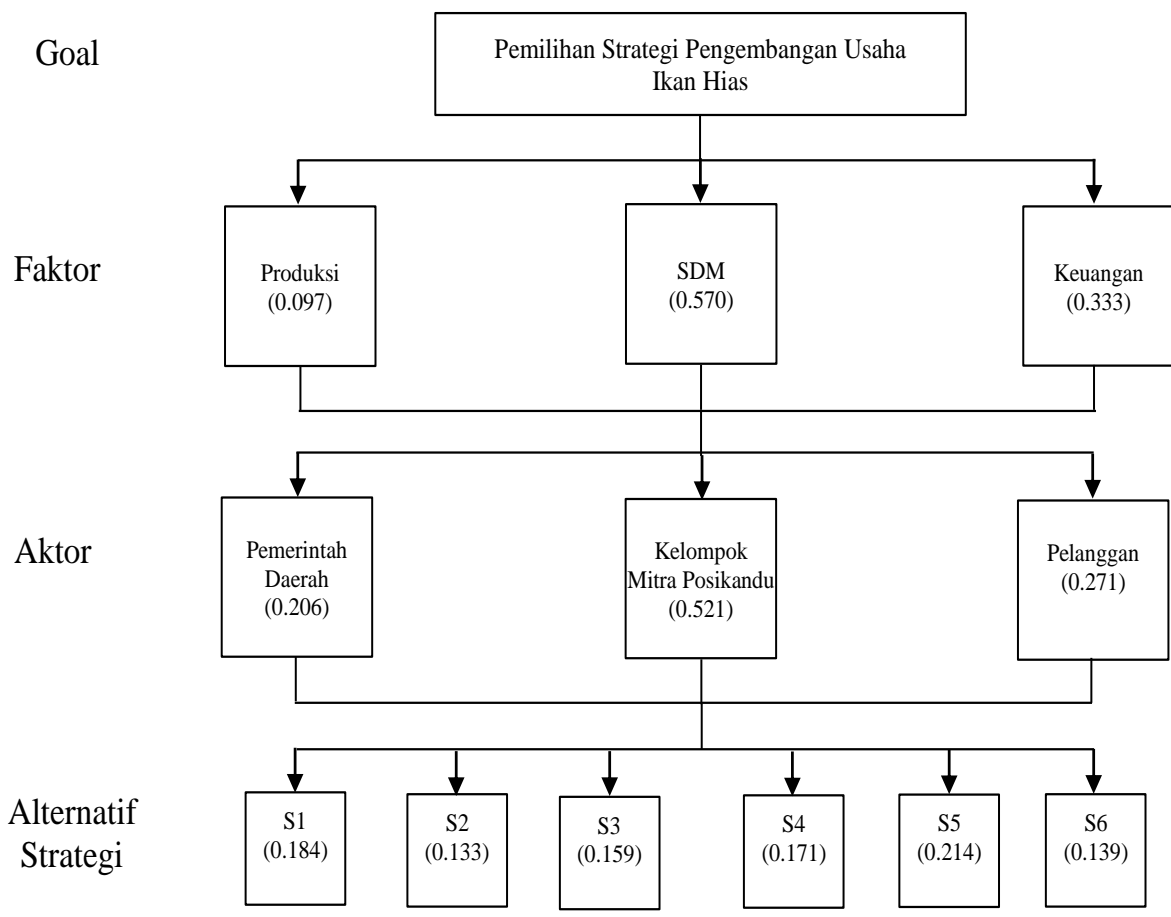

Gambar 7. Diagram alir pemilihan strategi pengembangan usaha budidaya ikan hias

implementasikan. Ini dilihat dari nilai faktor IFE komoditas ikan konsumsi senilai 3,06 dan IFE komoditas ikan hias senilai 3,12 ini berarti secara internal sangat mendukung dalam pengembangan usaha budidaya kedepannya. Begitu juga dengan nilai EFE dari komoditas ikan komsumsi sebesar 3,017 dan komoditas ikan hias sebesar 2,873. Ini mengindikasikan bahwa masih banyak peluang-peluang yang belum dimanfaatkan dengan baik.

3. Untuk segmen ikan konsumsi rekomendasi Strategi dari hasil perhitungan AHP adalah (S2) yaitu membentuk koperasi Mitra Posikandu yang di fasilitasi oleh Pemda Kabupaten Bogor $\left(\mathrm{S}_{1,2}, \& \mathrm{O}_{4}\right)$, sedangkan rekomendasi strategi untuk segmen ikan hias adalah (S5) yaitu mengikuti bimbingan teknis budidaya ataupun bimbingan usaha perikanan oleh pemerintah daerah $\left(\mathrm{W}_{2,4} \& \mathrm{O}_{4}\right)$.

\section{DAFTAR PUSTAKA}

Saragih. 2010. Agribisnis. Paradigma Baru Pembangunan Ekonomi Berbasis Pertanian. PT Bogor: IPB Press.

David, F.R. 2006. Manajemen Strategis Edisi Sepuluh. Jakarta: Salemba Empat.

Dinas Peternakan dan Perikanan Kabupaten Bogor. 2015. Buku Data Perikanan. Bogor.

Direktorat Jenderal Perikanan Budidaya. 2014. Laporan Tahunan Direktorat Jenderal Perikanan Budidaya. Jakarta.

Direktorat Jenderal Perikanan Budidaya. 2015. Laporan Tahunan Direktorat Jenderal Perikanan Budidaya. Jakarta.

Marimin, 2010. Aplikasi Teknik Pengambila Keputusan dalam Manajemen Rantai Pasok. Bogor: IPB Press.

Marimin. 2004. Aplikasi Teknik dan Aplikasi Pengambilan Keputusan Kriteria Majemuk. Jakarta: Gramedia Widiasarana Indonesia. 